\title{
'Strike out, right and left!': a conceptual-historical analysis of 1860s Russian nihilism and its notion of negation
}

\author{
Kristian Petrov ${ }^{1}$ \\ Published online: 4 March 2019 \\ (C) The Author(s) 2019
}

\begin{abstract}
The aim of this essay is to synthesize as well as to analyze the conceptual evolution of 1860s Russian nihilism in general and its notion of negation in particular. The fictitious characters that traditionally have been informing the popular notion of "Russian nihilism" mainly refer to an antinihilistic genre. By analyzing nihilism also on the basis of primary sources, the antinihilistic notion of nihilism is nuanced, enabling a more comprehensive analysis of the movement's different aspects. In some instances, Russian nihilism has been taken out of context and portrayed as a monolith; its pursuit of "negation" interpreted literally. In this essay, a dialectical relation emerges, between affirmation and negation on the one hand as well as between the nihilist "children" and their idealist "fathers" on the other. Despite its radical stance, nihilism consists of a reconciliation of opposites. Although nihilists fought for autonomy, revolution and a new society, the movement was ironically stuck in a continuous negation of its inspirers and forerunners.
\end{abstract}

Keywords Russian nihilism · Dmitry Pisarev (1840-1868) · Bazarov ·

Šestidesjatniki (generation of the 1860s) · Negation · Realism · Utopia · Cynicism

\section{Introduction}

In Ivan Turgenev's Fathers and Children $(F \& C)$ a "nihilist" is defined as "a person who does not bow down to any authority, who does not accept any principle on faith, however much that principle may be honoured" (Turgenev 1862/1981, 25). ${ }^{1}$ If the nihilist—from the Latin nihil, meaning nothing-ultimately is pursuing

\footnotetext{
1 Fathers and sons is the conventional translation, but Fathers and children, the literal translation, is a better reflection of the 1860s. While the "fathers" virtually exclusively consisted of men, the "children" encompassed both sons and daughters, nihilism itself significantly being a women's movement, in theory

Kristian Petrov

kristian.petrov@kau.se

https://www.kau.se/en/researchers/kristian-petrov

1 Department of Political, Historical, Religious and Cultural Studies, Karlstad University, 65188 Karlstad, Sweden
} 
nothingness, which seems as an implication in Dostoyevsky's novels (1872/1974, 93-94; 1880/1976a, 123), the nihilist is trapped in a paradox. Although the capacity to "negate" particularities, by means of perception, thought, desire or labour, hence transcending some of their actual or potential aspects, is fundamental to human existence and the development of self-consciousness (cf. Hegel 1807/1980), an intention to negate everything would result in a negation also of the very possibility of negation itself. This was indeed a common theme in 19th century Russian antinihilistic literature (cf. Turgenev 1862/1981; Dostoyevsky 1866/1973, 1872/1974). The act of absolute negation or repudiation here seems ultimately to imply selfnegation, taking, on part of the "negator", the form of personal misery, failure, madness or death.

Although the term was coined in late 18th century Germany, "nihilism" was via Turgenev's $F \& C$ introduced to a wider audience in the early 1860s Russia (MüllerLauter and Goerdt 1984), in the form of the loanword nigilizm. However, in contrast to other forms of nihilism, Russian nihilism did not imply, as one might expect from a purely semantic viewpoint, a universal "negation" of ethical normativity, the foundations of knowledge or the meaningfulness of human existence. Its negation was aimed at a most particular political, social and aesthetic regime (cf. Lovell 1998, 5) equivalent with Tsarist autocracy, religious orthodoxy, fine arts and, most notably, the ideas, attitudes and customs of the older generation. Accordingly, Russian nihilism was situated within an intergenerational cultural conflict which permeated Russian literature and society during the 1860s.

While fictional nihilists-Bazarov, the Underground Man, Raskolnikov, Stavrogin, Verkhovensky, Kirillov and Karamazov-have become universal cultural icons, ${ }^{2}$ actual nihilists and their ideas have not achieved the same renown. ${ }^{3}$ Although fiction, alongside historical documents, should be considered a fully valid source for understanding Russian nihilism (cf. Paperno 1988, 1-38), ${ }^{4}$ a peculiar aspect is that all of the aforementioned characters, who to a certain degree still inform the notion

\footnotetext{
Footnote 1 (continued)

and practice (see Siljak 2008, 53, 75; Stites 1978, 119; cf. Pozefsky 2003, 128). All translations from Russian in this paper are the author's.

2 For nihilism in Russian 19th century fiction, see Moser (1964), Schmidt (1974), Brumfield (1977), Višnjakova (2011), Thorstensson (2013) and Dubnov (2015). All translations from Russian in this paper are the author's.

3 This does not, however, mean that studies on non-fictional nihilists are absent. See e.g. Alekseev (1928), Coquart (1946), Novikov (1972), Brower (1975), Cochrane (1977), Kuznecov (1983), Kuznecov (1984), Paperno (1988), Elizavetina (1992-2003), Pozefsky (2003), Siljak (2008), Verhoeven (2009), Frede (2011) and Ely (2016). See also Thorstensson $(2013,3,4)$ for an overview of Soviet research into the history of the concept of Russian nihilism, a scholarly interest which is enrolled in a Russian tradition dating back to the 1860 s.

4 Pozefsky's $(2003,208)$ saying that "[19th century] Russians shaped their discourses just as their discourses shaped them", is instructive not only for nihilism but for the special status of literature in 19th century Russian culture. When literature was professionalized in Russia during the early 19th century it partly took over the role of the church as the mediator of truth, the novelist or poet being endowed with a social charisma to act as a spokesperson of the people, prophetically interpreting the signs of the time (see Petrov 2006, 314-315).
} 
of "Russian nihilism" within popular historiography, were created within an antinihilistic literary genre. ${ }^{5}$

Without ignoring the antinihilistic representation of nihilism this paper above all deals with the self-image of Russian nihilism from the viewpoint of nihilist writers and others sharing a common identity. The principal aim is to synthesize as well as to analyze the conceptual evolution of 1860 s nihilism in general and its notions of negation in particular, paying attention to several writers and activists, among them Dmitry Pisarev (1840-1868), frequently cited as the architect, apostle and leading intellectual of Russian nihilism (Billington 1970, 387; Vucinich 1988, 26; Stokes 1995, 148; Pozefsky 2003, 19). Alternative, more common investigative approaches would focus more exclusively on the context of Russian nihilism, regarding biographical, social and cultural aspects, at the relative expense of inherent conceptual dynamics (e.g. Coquart 1946; Pozefsky 2003; Frede 2011; Dubnov 2015), or, as indicated above, by primarily analyzing the movement through the prism of antinihilistic novels (e.g. Moser 1964; Thorstensson 2013). My interest concerns what nihilism, and other closely related concepts, actually meant in their own historical context, and particularly so when used by nihilist writers and activists.

The radical reception of Turgenev's $F \& C$ deepens our understanding of Russian nihilism. In this context the very term "nihilism" was, if not embraced, so at least tolerated and occasionally used self-referentially_as the nihilists saw themselves (cf. Pozefsky 2003, 9, 17). It is also here that Turgenev's fictional character-"Bazarov the nihilist", presumably reflecting a "new type" in the social sphere-was theoretically developed by non-fictional "Bazarovs". Indeed, the readers who themselves behaved like the novel's character, a phenomenon referred to as "Bazarovism", illustrate how art not only imitates life, but life itself imitates art. Alexander Herzen (1812-1870), who played a prominent role in the history of Russian nihilism, marvelled at how "actual persons grow into their literary shadows" (Herzen 1868/1968, 1752). According to Herzen, the social influence of Bazarov, as well as of characters in the novel What is to be done? (WITBD) (1863), echoes the supposed Werther effect in Germany one century earlier:

This mutual interaction of men on books, and books on men, is a curious thing. A book takes its whole stamp from the society in which it is conceived; it generalises, it makes it more vivid and sharp, and afterwards is outdone by reality. (Ibid.)

Certain revolutionaries of the late 1860 s indeed tried to emulate their literary role models (cf. Chernyshevsky 1863/1974, 274, 279) and, as Siljak (2008, 89, 107) suggests, they may actually have succeeded in becoming manifestations of such literary

\footnotetext{
5 To this genre above all belong works by Turgenev, Dostoyevsky, Goncharov, Leskov and Pisemsky (cf. Thorstensson 2013, i). One should, however, distinguish between outrightly polemical antinihilistic novels such as Leskov's No Way Out (Nekuda) (1864/1989) and Dostoyevsky's Demons (Besy) (1872/1974), on the one hand, and novels like Turgenev's Fathers and Children (1862/1981) and Dostoyevsky's The Brothers Karamazov (1880/1976a, 1880/1976b) on the other, portraying nihilism more empathetically (cf. Moser 1964, 116).
} 
examples in the eyes of their admirers. These revolutionaries in turn became archetypes that enabled further fictional popularization (cf. Dostoevsky 1872/1974). ${ }^{6}$

In general accounts, perhaps most notably in encyclopedia entries, the concept of negation has in relation to Russian nihilism many times tended to be overemphasized, taken out of context or interpreted literally (e.g. Olson 1967; Gillespie 1995; Kline 1999). In this essay, the interest concerns negation as well, although I treat it in a way which should be open to complexities, that is, its dialectical relation to affirmation, as well as its reconciliatory function in identity formation. A more nuanced view on Russian nihilism and its negative stance against idealism, romanticism and conventional morality can for example be found in Pozefsky (2003, 49-100). My attempt, however, is more characterized by a close reading of certain texts from a synthetic viewpoint of conceptual history, ${ }^{7}$ and particularly revolving around the notion of negation. ${ }^{8}$

The first part of this paper deals with Russian nihilism generically, in which its conceptual history, ideas, attitudes and expressions are approached (mainly) synthetically, hence partly providing a contextual framework for the textual analysis in the second part. In this part the nihilist thought of above all Pisarev, but also of Herzen and others, which is linked to the second more analytical section in part I, is focused more systematically.

\section{Part I: The 1860s and Russian nihilism}

\section{The conceptual and cultural history of Russian nihilism}

Although the term nihilism-perhaps most frequently used antagonistically by the authorities and the conservative press (Pozefsky 2003, 101)—eventually became closely connected to terrorism, it was initially associated with the student movement that had been seeking to advance personal autonomy, sexual liberation and solidarity with the poor masses. In the wake of the publication of Turgenev's $F \& C$, and a particularly influential review that Pisarev wrote about it, ${ }^{9}$ nihilism became as much

\footnotetext{
${ }^{6}$ Regarding Pisarev, the leading intellectual of Russian nihilism, not only did he endorse Turgenev's representation of Bazarov, Turgenev might actually have used Pisarev—alongside Chernyshevsky, Dobrolyubov and Bakunin — as a living model for his literary creation (Gillespie 1995, 149).

7 I agree with Quentin Skinner (1988, 260, 276), usually seen as one of the leading theoreticians of conceptual history, that ideologically charged concepts, or, as he rather says, utterances, are not stable entities of discourse, merely reflecting the social world. Rather, they should be seen as active instruments in motion, with which to achieve specific ends, also affecting the context.

${ }^{8}$ Negation will here above all be used in a conventional sense, as a logical denial of truths and ideals, but in some instances also metaphorically as a practical "denial", i.e., destruction, of the surrounding world. Negation and destruction (or rather-considering a Russian 19th century context-the German Negation, Verneinung or Ablehnung, on the one hand, and Zerstörung or Destruktion, on the other, or corresponding French equivalents), can be rendered variously in Russian, but most commonly as otricanie and rasrušenie respectively.

9 Pisarev's review in 1862 spawned the definitive popularity of nihilism in Russia. Russian nihilism in the West, however, was not popularized until later, starting with an overview article published by Herzen
} 
a fashion and life-style as an intellectual outlook. In this context nihilism signifies a conflation of a set of action-oriented ideas (about sex, marriage, emancipation, progress) and the characteristic people that embodied them, that is, the alienated sons and daughters of the aristocracy, clergy and the middle class. The typical nihilist would hang around the university campus (cf. Brower 1975), walking around with a thick copy of Feuerbach hidden under dark clothing, aspiring, like Bazarov, to become a physician, or daydreaming about starting a cooperative sewing commune, like the heroine Vera Pavlovna in WITBD.

These nihilists' anti-authoritarian attitude, as well as their sense of collective solidarity with the underprivileged, were particularly emphasized by their dress code (see Stites 1978, 103-105; Siljak 2008, 52; Paperno 1988, 17-19). Young nihilist men dressed in ill-fitting dark coats, aspiring to look like unpolished workers, let their hair grow bushy and often wore blue-tinted glasses. Correspondingly, the young women cut their hair shorter, wore large plain dresses and could be seen with a shawl or a big hat, together with the characteristic glasses. Such a nihilist could, however, above all be identified by a reversal of official etiquette (see Siljak 2008, 52; Stites 1978, 104; cf. Chernyshevsky 1863/1974, 124-25, 272; Pisarev $1864 / 1956,87)$; the men demonstratively refusing to act chivalrously in the presence of women, and the women behaving contrary to expectations. Both sexes hence sought to incarnate Bazarov's roughness, his "cynicism of manner and expression" (Herzen 1868/1968, 1751).

Ironically, however, the term nihilism had originally been communicated to the younger generation by those who would be seen as their intellectual fathers, those against whom the new generation rebelled—not least by using the very word "nihilism". It is true that Dobrolyubov, a šestidesjatnik (a man of the sixties), ${ }^{10}$ and an intellectual occasionally seen as a leading nihilist, had used the word sporadically (Zrjačkin 2009, 19-34). ${ }^{11}$ Even so, the term nihilism did not become popular until Turgenev published $F \& C$ in 1862. Turgenev (Turgenev 1862/1981, 25, 119), a sorokovnik (an 1840s man), used the term to describe "the children", the new generation of students and intellectuals who, by virtue of their relation to their fathers, were considered šestidesjatniki. Thus, the concept of nihilism had been coined in Russia to characterize the spirit of a generation.

However, neither Turgenev nor Dobrolyubov were the first to reference nihilism in Russian history. The liberal-conservative and romantic literary critic and

\footnotetext{
Footnote 9 (continued)

in 1864 in a Belgian journal and one by Pëtr Boborykin in 1868 in a British journal (Thorstensson 2013, 4).

${ }^{10}$ For the sake of accuracy, throughout this paper I will use the Russian šestidesjatniki (sixties people) as a direct loan. Correspondingly, the Russian sorokovniki refers to the preceding generation associated with the 1840 s.

11 Dobrolyubov, perhaps himself a role model for Bazarov (Freeborn 1998, viii), came to the term nihilism through the šestidesjatnik and sociologist Vasilij Bervi-Flerovskij (1829-1918). In 1858, BerviFlerovskij used nihilism as a synonym for scepticism (Zrjačkin 2009, 19-34; Thorstensson 2013, 4), a meaning closer to contemporary definitions of nihilism in a Western context.
} 
ethnographer Nikolaj Nadeždin (1804-56) had used the term in a philosophical article in 1829, addressing epistemological sceptics, whom he called "deniers" (quoted in Thorstensson 2013, 3-4). Its intended meaning was denigrating, and implied that the sceptics literally understood "nothing" (Fandozzi 1974, 3). Interestingly, Mikhail Katkov (1818-1887), a renowned conservative publicist, had also used it pejoratively in describing radicalization within his own generation, the sorokovniki, who supposedly no longer believed in anything (Katz 1966, 31; Fandozzi 1974, 3). Other sorokovniki, like Vissarion Belinsky (1811-1848), had symptomatically employed the term in a more neutral sense (Müller-Lauter and Goerdt 1984, 854; cf. Alekseev 1928).

It was, however, Turgenev's Bazarov, the protagonist of $F \& C$, who became the most iconic portrait of a nihilist, and regarded as a paragon by the šestidesjatniki in particular. Bazarov states that he does not believe in anything-except for the practical benefits of science. He and his compatriots turn against the older liberals, idealists and Hegelians (Turgenev 1862/1981, 25), hence constructing a generational identity that polemically is against the sorokovniki. Ironically, the novel offers a moral critique of nihilism, yet it is not overtly antagonistic as is much of the rest of the antinihilistic genre that was developing during the 1860s-1870s. What made it easier for the younger generation, and radicals among the sorokovniki as well, to merge Bazarov into their own ideological reflection was that, despite the critical sting embodied in Bazarov's caricature-like representation, he was nevertheless made with sympathy: while egocentric, insensitive, uncultivated, isolated and dogmatic, Bazarov is also independent, unaffected, fearless, anti-authoritarian and virtually altruistic.

The generational conflict that was introduced in $F \& C$ was re-interpreted in Chernyshevsky's WITBD, which came to play an immense role for the young radical 1860s generation, if not for the development of the revolutionary movement up to October 1917 (cf. Frank 1967, 68). ${ }^{12}$ Despite that certain sorokovniki not only had acted as mentors for the šestidesjatniki but also must be considered as authentic radicals — or even nihilists - in thought and deed, Chernyshevsky chose an interpretation of the generational conflict which unilaterally favoured the young. ${ }^{13}$

Alongside $F \& C$, the novel WITBD appears as the greatest source of nihilistic inspiration from the early 1860s (cf. Paperno 1988, 17). "Nihilism", however, is nowhere mentioned in the latter. This would certainly have been a clever move for

\footnotetext{
12 For an initiated discussion about the continued influences of Chernyshevsky on political thought in a Soviet context, including changes in reception and status, see Scanlan (1967).

13 Russian nihilism was essentially a product of the 1860s evolving dialogue between sorokovniki and šestidesjatniki, in which both generations, or groupings or members therein, participated alternately as subjects and objects, speakers and listeners. Accordingly, nihilism, as a movement, did not exclusively consist of šestidesjatniki. Indeed, sorokovniki like Bakunin and Herzen held nihilistic views and contributed to the nihilists' cause. One should, however, remember that some significant differences remain between the nihilist "fathers" and the nihilist "children". According to Carr (1937/1975, 376), Bakunin's denial of the social order was essentially romantic and based on "an unlimited faith in human nature". Although Herzen could be qualified as a nihilist in several senses, he was by virtue of belonging to an older generation, supposedly prone to philosophical idealism, still regarded as an "other" by some of the canonized nihilists among the 1860 s generation. In Dubnov's $(2015,35)$ words, "nihilism" is to a great extent "a signifier of generational schisms" which also corresponds to the view taken by both the liberal and conservative critics of nihilism, from Turgenev to Semyon Frank, that one should not, regarding nihilism, blur the distinction between the sorokovniki and šestidesjatniki (cited in ibid., 20, 26).
} 
anyone who intended to avoid censorship, but the absence of the word also confirms Chernyshevsky's negative attitude towards it, seen as a label invented by the authorities for derisive purposes. There is, however, no doubt that he was speaking up for the same political cause as other recognized "nihilists" did, which might excuse the association of him in this context with the nihilist movement. First, the book's title alludes to Pisarev's positively nihilist interpretation of Bazarov. Pisarev (1862/1955, 50) does, in the last paragraph of "Bazarov", twice put the question "What is to be done?", regarding allegations against Bazarov and the new generation for only offering emptiness, meaninglessness and passivity. Chernyshevsky (1863/1974) thus accepts Pisarev's challenge to formulate an alternative or, one might add, a vision of how negation can be reconciled with affirmation. Secondly, in the novel, the narrator's identification with the "children" is strong (ibid., 306), and like Bazarov, all the narrative's three heroes study medicine; Lopukhov and Kirsanov also dissect frogs and cherish the same idols as Bazarov do (ibid., 62, 159, 352). Thirdly, individual independence is the central value and reason, feeling and egoism shun no convention (ibid., 72, 352). It is also said that "something will go under" with reference to the apocalypse (ibid., 160, 265, 270), although a "Golden Age" is supposedly awaiting (ibid., 173-84, 246, 374-84).

The progressives of the older generation, like Herzen and Turgenev, had received their ideological schooling during the 1830s and 40s. The ideological development of the šestidesjatniki occurred in the aftermath of the revolutionary events in Europe in 1848 which coincided with the most repressive rule of Tsar Nicholas I. Chernyshevsky (1828-1889), one of the older šestidesjatniki, was initially influenced by sorokovniki like Herzen and Belinsky, and also Turgenev, but was politically radicalized in the late 1850s. Like his generational compatriots, he had been introduced to German materialism, French utopianism and British utilitarianism (Walicki 1979, 186-87; Moser 1964, 29-31), ${ }^{14}$ merging ideologies of radicalism and positivism.

Both sorokovniki and šestidesjatniki criticized the current regime, but the former-irrespective of whether they could be seen as having liberal or socialist orientations - to a greater extent laid their critique on a foundation of Hegelian idealism, identification with Europe and belief in civil liberties and humanism (Walicki 1979, 115-117; Carr 1937/1975, 106, 376; Malia 1961, 331). If many sorokovniki by the iconoclastic šestidesjatniki were considered critics in words, these šestidesjatniki

\footnotetext{
14 Among the German materialists, the šestidesjatniki, i.a., read Büchner and Feuerbach (Moser 1964, 30, 36). Chernyshevsky also took deep impressions from Fourier and his idea about the emancipation of the passions. Fourier's status is indicative of a deeper connection between Russian nihilism and the French utopian revolutionary tradition. To this tradition, in which the aesthetic concept of avant-garde was coined, one can associate names such as Saint-Simon and Fourierist Gabriel-Désiré Laverdant, the latter who attributed to art the role of wiping society clean, of mysticism and injustices (see Bäckström 2010, 61-62).
} 
presented themselves as critics in deeds (cf. Chernyshevsky 1863/1974, 86, 191); their attitude being less conciliatory towards the regime (Billington 1966, 387-390).

Considering these conditions, the identity of many of the younger nihilists was not ultimately formed in contrast to the institutions that they ideologically intended to "negate", namely, the Tsar, church, law, family and repression; rather, they emerged dialectically within the relation to their predecessors and inspirers. ${ }^{15}$ The term nihilist, I suggest, in its significant association with the šestidesjatniki, should in this context be understood in relation to the idealist of the sorokovniki generation. Those šestidesjatniki-nihilists share their identity, however, not only with having challenged and succeeded previous ideologies, but through shared dependence on, (selective) inclusion of, and (radicalized) continuity with extant ideology.

A series of mutually constitutive oppositions is at the core of the self-image of the radical šestidesjatniki, revealing perspectives about the relation between "fathers" and "children" and indicating the dialectical character of nihilist ideology: nihilists-idealists; raznočincy ${ }^{16}$-aristocrats; radicals-liberals; revolutionaries-reformists; people of action-people of words; practitioners-theorists; capable people-superfluous people (cf. Billington 1970, 390). Accordingly, generational outlooks do not succeed one another simply and cleanly; rather, there is overlap. Sorokovniki, like Herzen and Mikhail Bakunin (1814-1876), not to mention Turgenev, probably contributed as much to the theoretical impulses of nihilism as did the šestidesjatnik Pisarev. Even earlier, older generations had pejoratively depicted the sorokovniki as nihilists (Katz 1966, 31). And, among the šestidesjatniki, the term for the sorokovniki was "superfluous people", which had been the sorokovniki's critical description of themselves during Nicholas I (cf. Herzen 1860/1968, 1575).

The conceptualization of opposing, yet balancing, elements was never carved in stone; rather, it developed dialectically toward increasing radicalization. For example, Herzen notes that in the beginning liberal critics called the radicals "materialists"; but then, when it was no longer sufficiently derogatory, they came to prefer the term "nihilists" (Kuznecov 1983, 548). Pisarev, when being depicted by others as a nihilist, rather presents himself as a "realist" ${ }^{17}$ The term "realist" shares with "nihilist" a critical sting: Realists deny the dirt, falsity, irrationality and injustice in that which is obsolete (but not what is substantially real or coming). Although realism,

\footnotetext{
${ }^{15}$ Cf. how Herzen $(1868 / 1968,1753)$ came to regret how the younger generation essentially shared the same desires and values regarding society and culture as the "best men" of the preceding generation did, but had paradoxically taken an unfriendly and mocking attitude towards the older generation.

16 It has frequently been stressed that many of the šestidesjatniki were so-called raznočincy (people of various ranks), which means that there would have been greater social diversity among them than would be found in the older generation, comprised of mostly ethnically Russian nobility from St. Petersburg or Moscow (e.g. Billington 1970, 385-86; cf. Paperno 1988, 16). This is true to a certain extent. But the historiographical tendency to equate nihilism with raznočincy has rightfully been criticized (see e.g. Ely 2016, 61). Many of the prominent šestidesjatniki were of noble birth like their "fathers", or at least children of clergymen, both lacking first-hand experience of repression and poverty, although they knew about them from the "thick journals" (Siljak 2008, 42).

17 "Realists" have the same referent as "nihilists"; the character chosen by Pisarev $(1864 / 1956,86)$ to represent "our realism" is Bazarov, the "representative of our young generation" (Pisarev 1862/1955, 8)-the archetypical nihilist.
} 
like nihilism, implies the rejection of metaphysics, sophistry, sentimentalism and aestheticism, it may, however, harbour a more positive and objective approach to reality, in contrast to nihilism and its connotations of subjectivism and nothingness.

Though the sorokovniki had provided the šestidesjatniki with theoretical grounds for ideological advancement, the two generations became increasingly confrontational towards each other. It has even been suggested that it was particularly the raw manners of some of the šestidesjatniki that did not harmonize with the sorokovniki and their aristocratic refinement (e.g. Siljak 2008, 62; cf. Frede 2011, 207). ${ }^{18}$

An event that would serve to radicalize the nihilist movement, and further alienate the "children" from the "fathers", occurred in 1866 with the attempted assassination of Alexander II. Consequently, the government's efforts to reform society faded and the social climate shifted in a way that confirmed the nihilists' uncompromising worldview (cf. Billington 1970, 395; Lincoln 1990, 173; Walicki 1979, 225).

Sergei Nechayev (1847-82), a name associated with terrorism, political ruthlessness and immorality, appears during this period of radicalization (cf. Siljak 2008, 96-97). Nechayev is usually described as a central character in the history of Russian nihilism, taking "negation" out of aesthetics and literature into the social and political realm. According to Carr (1937/1975, 375) Nechayev was, however, more caricatural than typical of the radical šestidesjatniki, and he was certainly not of the intelligentsia like Pisarev or Dobrolyubov. ${ }^{19}$ Nonetheless, Nechayev was for a shorter period Bakunin's protégé and they collaborated to write a catechism that set the principles for a new type of professional revolutionary activity (Nechayev $1869 / 2010) .^{20}$

In the Catechism, ends sanctify the most unscrupulous of means, indicating that "negation", or rather destruction, has no limit. Any challenges to revolution are judged immoral, regardless of circumstances. Interestingly, terrorist methods are not legitimized with reference to a social alternative, but justified as paving the way for destruction on a wider scale, the Revolution. Accordingly, the goal is "the quickest and surest annihilation of the existing order", echoing Bazarov's as well as Bakunin's view that, currently, the most important task is to "clear the ground" (Turgenev 1862/1981, 49; Berlin 1994, 299). Only later will the shape of what is coming be visible and a new order achievable.

\footnotetext{
18 Cf. also Nahirny $(1962,402,405)$ who contends that the social orientation of radical ideological groupings in Russia during the second half of the 19th century was necessarily irreconcilable and dualistic. Accordingly, the ideal recruit emerged among the youth - uprooted, alienated and standing outside conventional social ramifications.

${ }^{19} \mathrm{Cf}$., in this context, the distinction within the nihilist movement between "salon"- and "plebeian" nihilists (Paperno 1988, 16), to which Nechaev would belong to the latter.

20 On the close, albeit troublesome, relation between Bakunin and Nechayev, see Carr (1937, 375-393). Gillespie (1995), e.g., looks at Nechayev's revolutionary activities as a logical consequence of Bakunin's and Pisarev's theoretical "nihilism". Disregarding the extent to whether Nechayev's thoughts and actions can be qualified as "nihilistic", it seems that he deliberately tried to stage himself as Chernyshevsky's nihilistic novel character Rakhmetov, the quintessential revolutionary, equally dedicated and mysterious, and he also had a special fondness for turning to those young people who by virtue of their attire and opinions could be identified as nihilists (cf. Siljak 2008, 89, 92).
} 
In Nechayev's Catechism, the revolutionary is "a doomed man", a person with no social attachment, save to his revolutionary organization. ${ }^{21}$ But solidarity with fellow conspirators is, nonetheless, conditional to what benefits the Revolution- the sole intrinsic good. Such ideas, confirmed by the murder in late 1869 of the revolutionary student Ivan Ivanov, who had begun to question some of Nechayev's metods, upset the establishment, inspiring Dostoevsky to write a novel, Demons, that characterized the whole revolutionary movement in an accusatory light. Here, the essence of nihilism did not appear as political or social activism, but as existential decline with diabolical dimensions (cf. Carter 2015, Ch. 8).

\section{The philosophy of Russian nihilism}

When nihilism originated as a term in the late 18th century German-speaking world, it was mainly used as a polemical marker within philosophy, theology and aesthetics directed against far-reaching idealism, subjectivism and radicalism (Müller-Lauter and Goerdt 1984). These philosophical roots of nihilism seem to have encouraged certain scholars to search for wider philosophical implications also when it comes to Russian nihilism. Accordingly, Gillespie (1995, 138), ${ }^{22}$ for example, sees the Russian political movement of nihilism as an extension of the German debates on idealism. For him, Russian nihilism is a quest for "radical autonomy" (ibid., 140), calling for negation of the institutions of repression. In turn, this presupposes a belief in "the causal power of human freedom" (ibid., 141), which Gillespie derives from Johan Gottlieb Fichte's philosophy of subjective idealism.

Although Gillespie approaches Russian nihilism more speculatively than empirically, this link between idealism and nihilism is not entirely a construct. The šestidesjatniki indeed rejected idealism; their masters, however, like Herzen and Bakunin, had found understanding in the philosophies of Fichte and Hegel. So, even if nihilism in 1860s Russia represented a cultural and political movement rather than a metaphysical or epistemological system, traces of Fichte's idealism might be found in its discourse, despite its materialistic and realistic rhetoric. ${ }^{23}$ Consider for example Fichte's idea about the absolute $I$, which is set to negate the Not-I, corresponding to Chernyshevsky's (1863/1974, 270-71, 283) concept of New Man and Special Man, as well as to Bakunin's idea of the revolutionary-as-the-new-Messiah (Siljak 2008, 101). These "new types", to borrow Pisarev's designation, dare to break any taboo in order to liberate the individual or the people, or make reality more rational and just:

\footnotetext{
${ }^{21}$ Cf. how Pisarev (1865/1956b, 47) characterizes the "Rakhmetovs".

22 Gillespie's monograph, Nihilism before Nietzsche (1995), has since its publication been frequently cited in the literature on Russian nihilism, but it should be stressed that Gillespie is a political philosopher mainly interested in the German history of philosophy and the relation between modernity and theology, rather than being an expert on Russian nihilism, philosophy or history.

23 Cf. Paperno (1988, 7) who highlights how 1840s romanticism and idealism were echoed in the 1860 s. See also Randolph (2011, 196-204) on the relation between idealism and radicalism in Bakunin.
} 
No matter how beautiful and consoling any worldview is, no matter how many centuries and peoples considered it an irrefutable truth, no matter how many world geniuses bowed before its power of conviction-the most modest of the new people will accept it only if it suits the demands and make-up of his own reason. Each new man has his own inner world in which his own personal person rules with unbounded dominance [...] (Pisarev 1865/1956b, 23-24)

The anarchist and Hegelian Bakunin, one of the spiritual godfathers of the ideology of the šestidesjatniki, participated in demonstrations and rebellions against authority and oppression throughout the European continent (Siljak 2008, 100). His political dedication corresponded to a more idealistic and a romantic view on the World Spirit's dialectical strife toward self-consciousness, which he especially cherished during his youth:

Let us therefore trust the eternal Spirit which destroys and annihilates only because it is the unfathomable and eternal source of all life. The passion for destruction is a creative passion, too! (Bakunin 1842/1972, 57)

By promoting the role of negation, against the political as well as divine sovereign, Bakunin provided the radical movement with a pre-Marxist Hegelian impetus. But if Hegel had seen his own time as history's end point, Bakunin, the Left Hegelian, offers a more restless view on history, cherishing the value of negating that which exists for the sake of what has not yet become. Symptomatically, Bakunin, along with Nechayev, developed the concept of terrorism as having an anti-state utilityconstituting an inverted mirror image of the medieval, inquisitorial Jesuit order and the Machiavellianism of the modern state (e.g. Siljak 2008, 102). The conspirators' strategy to spread fear and destruction under the pretext of discovering what might remain, looks to bring such discoveries into the future.

Another ideological precursor of Russian nihilism was Herzen, not only by virtue of his association with the šestidesjatniki but also by his belief in the power of negation. Although Herzen many times seems ambivalent in his political views, in a preface to a renowned book which was dedicated to his son, Herzen writes straightforwardly, "We do not build, we break (lomat'); we do not announce a new revelation, we remove the old lie." Modern man, he continues, "only builds a bridge", since it is for "the unknown man of the future to pass over it". He urges his son to enter the bridge, at any cost, although the crossing of it would lie beyond the immediate horizon (Herzen 1855/1955, 9). The destroyer thus has an objective beyond destruction itself, even though, as the character Bazarov says, it would at present be more strategically appropriate to focus on negation.

Negation, in the form of denial, rejection or even destruction, is not, as I understand it, something self-sufficient: it can coexist with affirmation (to the extent that nihilism also holds a utopia), or may serve the latter by means of "clear[ing] the ground". Even "negation" as advocated by Bazarov is not limitless. It is aimed at current institutions and conventions. Tellingly, Bazarov says he does not stand for anything in particular, but he intends to clean up and create opportunities for others (Turgenev 1862/1981, 49). Negation is not, for example, targeted at the practicality of science to maximize social benefit and the improvement of humanity (ibid., 28); 
rather, the eternal truths of idealism, the classicism and romanticism of literature and art, as well as religion and morality are rejected, and with them "science" as a system or a body of collected knowledge (Turgenev 1862/1981, 28, 49; cf. Nechayev $1869 / 2010, \S 3) .{ }^{24}$ Bazarov is particularly impressed by the technological potential of science. In that form, nihilism is close to positivism as a doctrine directed against metaphysics, which would strip off what is non-sensuous and unnecessary. The nihilist's concept of truth is, therefore, essentially pragmatic: What is true is that which is viable and useful (cf. Herzen 1868/1968, 1752).

The people that emerged as "nihilists" in the world outside of fiction, or in the form of "new people", all had in common with the fictional character Bazarov a disrespectful attitude towards authority and tradition. Unlike Bazarov, however, those nihilists presented a clearer picture of how society should be rearranged. Bazarov was by non-fictional nihilists praised for his uncompromising and rational "egoism" but for them the negation needed to be complemented with an affirmation. Such an affirmation was provided by Chernyshevsky (1863/1974, 374-384) in utopian form in Vera Pavlovna's famous dream in the fourth chapter of WITBD. ${ }^{25}$ If Turgenev's Bazarov had given the new generation an identity (cynicism) and confirmed their beliefs (materialism), Chernyshevsky's fictional characters Vera Pavlovna and Rakhmetov informed their mission. The task was to unify attitudes of individual emancipation and self-interest with the cooperative organization of life- and community-promoting work, performed in rational harmony, whether to be achieved peacefully or violently. ${ }^{26}$

However, the affirmative implication of negation is in some respects not evident. The term "principle", with its romantic-idealistic connotation, is for Bazarov a derogatory word (Turgenev 1862/1981, 48). This attitude seems to indicate that negation in some instances should not be limited to the elimination of the deficiencies and constraints of existing social convention. In Nechayev's Catechism, principle along with polite manners acquire negative connotation, but so can even more fundamental concepts like that of emotion. Emotions that motivate basic human expressions, e.g. kinship, love, friendship, gratitude or honour, are "enervating"

\footnotetext{
${ }^{24}$ The WITBD protagonists Kirsanov and Lopukhov are symptomatically described to mock medicineas institution and science-but enthusiastically devote to it with their every effort-as practice and study of knowledge (Chernyshevsky 1863/1974, 62).

25 The dream's dramatic character is invoked by its anticipating run-up being deliberately omitted. This might have been a way for the author to elude censorship, while it also could have inspired the initiated readers to radical action by inviting them to write the book's end with their own lives (see Siljak 2008, 81).

${ }^{26}$ Chernyshevsky $(1863 / 1974,169-81,374-84,388-89)$ presents a utopia about a coming golden age, in which a technologically advanced civilization had developed. Humans master nature and machines carry out heavy labour. This civilization is based on the rational organization of collective cooperation but is at the same time promoting the individual's independence and talents. Chernyshevsky is, however, more specific regarding the immediate future. The road to utopia is not only spelled as agitation, enlightenment and revolutionary action, as forms of negation and destruction. Vera Pavlovna establishes a sewing shop, functioning as a role model for how the future should be realized. The sewing commune is based on the principles of cooperation (collective meals, common accountancy, no owner profit, social responsibility, work effort according to individual capability/collective need) as well as education (reading aloud in the shop as well as doing recreational activities in the countryside or visiting the opera).
} 
(izneživajuščie) and should be suppressed for the sake of "the cold passion [strast'] for the revolutionary cause" ( $(6)$. Even family members, close friends and sincere devotees of the revolution, according to Nechayev's manifesto, may under certain conditions be sacrificed for the great cause. Pisarev too describes approvingly how future revolutionaries ("Rakhmetovs") carry forward the banner of the era, and whose mission "has long ago taken the place of near ones and loved ones" (Pisarev 1865/1956b, 47).

In various nihilistic documents a theoretical dualism resides that corresponds to the movement's essentially antagonistic identity formation, as seen above. Against negatively loaded words - such as principle, heroism, doctrine, idea, idealism, dogma, schematism, law, convention, manners, emotion, heroism, romanticism, dreaminess, beautiful ideas, God, religion, tsar, authority, exploitation, marriage and obsoleteness - stands a sequence of positively loaded words. These include experience, empiricism, science, reason, calculation, logic, utility, action, activity, progress, materialism, realism, equality, independence, passion, egoism, self-interest, force, movement, life, youth and freshness. ${ }^{27}$ Besides indicating the worldview of Russian nihilism, this dualistic conceptualization also illustrates why basic concepts are never merely passive reflections, but rather active resources, constantly validating or invalidating the status of the sender or the receiver of a specific message. Several of the aforementioned words might be used rather neutrally, but mostly they acquire a distinctly positive or negative connotation depending on the users and their purposes, the presumed referent and the specific situation.

Even in those cases in Russian nihilist tradition when negation appears in its most extreme form-remarkably so in Bakunin and Nechayev, and in some respects also in Herzen-it is nevertheless not absolutized, despite the tendency to go beyond convention. Society as such is never negated (cf. Pisarev 1864/1956, 87), but society in its current, i.e., archaic form, for the benefit of society as it will become in the future (cf. Herzen 1855/1955, 48). Strictly speaking, it is not a potentiality that is posited against an actuality, which could be an interpretation of Bakunin's (1842/1972, 55) advocacy of conditioning the future by "the negation of existing conditions"; but, rather that the destroyer should enable the rationality of that which will be coming to prevail over the irrationality of that which has already begun to disappear (cf. Gillespie 1995, 150).

Herzen, reflecting his Hegelian background, ${ }^{28}$ defines nihilism as a positive force. The goal is not "nothing" and the means to achieve it is not "negation", i.e., of anything really existing. The nihilist negates that (irrationality) which is only nominally existing:

Nihilism [...] is logic without structure, it is science without dogmas, it is the unconditional submission to experience and the resigned acceptance of all consequences, whatever they may be, if they follow from observation, or are

\footnotetext{
27 Cf. Turgenev (1862/1981, 25, 48-49, 51), Chernyshevsky (1863/1974, 29, 72, 86, 92, 94, 125, 160, 186, 221, 242, 265, 270, 284, 415; 1860/1974, 278-80), Herzen (1868/1968, 1751-52, 1762, 1764), Nechayev (1869/2010), Pisarev (1865/1956b, 9, 20-21, 31; 1862/1955: 9, 25).

28 For a good overview of Herzen's Hegelian view of history, see Malia (1961, 313-318).
} 
required by reason. Nihilism does not transform something into nothing, but shows that a nothing which has been taken for a something is an optical illusion, and that every truth, however it contradicts our fantastic imaginings, is more wholesome than they are, and is in any case what we are in duty bound to accept. (Herzen 1868/1968, 1764)

That nihilism would lead to scepticism, despair and inactivity, by turning "facts and thoughts into nothing", is, according to Herzen (1868/1968, 1764), a popular delusion. The very foundation of Russian nihilism seems to be the negation of the supposedly irrational, false and unjust-for Herzen, that "nothing", which so far has deceived us as "something", in Pisarev's $(1865 / 1956 b, 9)$ words formulated as any "deformation (bezobrazie) [...] that weighs on the earth and darkens the sky"-with the aim of emancipating the individual from the constraints of society, family and religion (Pisarev 1864/1956, 83; cf. Walicki 1979, 210). The negation of deformation is the fundamental theme, though the negation goes hand in hand with an affirmation, in the quasi-Christian yet formally secular utopia of a perfect society, where love can be acted out guided by the interest of "common utility and rational work" (Pisarev 1864/1956, 82):

These people [i.e. "new people"] are fanatics, but they are fanaticized by a sober thought and are drawn towards the unknown distance of the future by the very definite and earthly desire to give all people in general the largest possible share of common earthly happiness. ${ }^{29}$ (Pisarev 1865/1956b, 8)

Dostoyevsky would agree that Russian nihilists are "fanatics", a view that should instruct our further analysis. In accord with a polemical agenda, and in correspondence with the Russian authorities' increasing association of nihilism not only with bloodshed but also ethical collapse (cf. Schapiro 1978, 183-190), Dostoyevsky drew the allegedly unintended consequences of Russian nihilism. Eventually, such farreaching conclusions would become instrumental for those who began using "nihilism" as a derogatory term for the destructive aspects of modern culture in a more generic sense, encompassing the ideology of radicalism, which was seen as being adulterated by scepticism and atheism. The consequences drawn by Dostoyevsky and his followers have actually had such an impact on the subsequent cultural understanding of nihilism, that one can hardly ignore them, even when considering the original ideas of Russian nihilism (cf. Dubnov 2015, 25).

In The Brothers Karamazov in particular, Dostoyevsky illuminated the existential aspects of nihilism. Ivan - the rationalist and atheist middle brother-is supposed to have said that "Without God [...] everything is permitted" and also suggesting that "[s]ince there is no God", the soul has "no immortality". In conclusion, without immortality (and no Last Judgement), "there's no virtue" (Dostoyevsky 1880/1976b,

\footnotetext{
${ }^{29}$ Symptomatically, the other two great mentors of the young radical (and atheist) generation, Dobrolyubov and Chernyshevsky, and to whom Pisarev was intellectually and morally indebted, were sons of priests. See e.g. Paperno (1988, 206-218) regarding religious motives and allusions in Chernyshevsky's works.
} 
29). ${ }^{30}$ And without virtue, nothing could be considered moral—or immoral. Hence, when one denies God, one also releases all restriction imposed on humans for not living out their egoism and performing criminal or evil deeds.

The message in Karamazov is clear: Denial of absolute truths leads to a state where ethical standards can no longer be justified. In Europe, cultural critics alongside confessional Christian thinkers could argue, particularly as seen in the light of Dostoyevsky, not only whether degeneration and immorality were natural effects of nihilism, but whether the nihilist lived in a mood of emptiness, atrophy and despair. Without a shelter against relativism or a sustainable guide to normative behavior, individuals would be lost in cosmic solipsism. Presumably, nihilists would remain in a state of existential crisis if they did not resort to a power within themselves that would draw them towards a new dogmatic worldview (cf. Andrén 2014, 210-212).

\section{Part II: "...an incarnation of the theory of nihilism..."}

\section{The Bazarovism controversy}

Quite in contrast to Dostoyevsky, nihilists like Pisarev believes that radical "fanatics" will do good things, motivated by their very fanaticism. ${ }^{31}$ Denial of society's professed absolutes, an act which for Dostoyevsky would pave the way for fathomless immorality and tangible destruction, is for intellectuals like Pisarev, and also Herzen, legitimized as a step towards affirmation —of that which is real, hidden behind the deformations that "darkens the sky".

Pisarev was born in 1840 to an aristocratic family. Thus, he was younger than other contemporary writers, like Chernyshevsky and Dobrolyubov. The latter two had collaborated to publish in the periodical Sovremennik (The Contemporary), while Pisarev was one of the most prominent writers for Russkoe slovo (The Russian Word), the two most influential (and amongst themselves competing) public organs of radical opinion (Coquart 1946, 66-81; Kuznecov 1983, 538)—Russkoe slovo in many respects being the intellectual vehicle of Russian nihilism. Pisarev completed university studies in the same year that serfdom was abolished, which also coincided with the first major student demonstration in St. Petersburg (see Siljak 2008, 33; Coquart 1946, 25). Emerging as a prophet for the new generation, he had the possibility to introduce nihilism or "Bazarovism" to the St. Petersburg student movement.

Pisarev's education and career were affected by reoccurring mental crises and four years of imprisonment at the Peter and Paul Fortress, where he was initially prohibited from writing. After prison, isolated from family and professionally disoriented, he became physically exhausted and depressed. Although he seemed confident in his eventual recovery, tragedy prevailed. Pisarev died in a drowning accident

\footnotetext{
${ }^{30}$ It is, however, unclear whether the reader in this should see a genuine conviction supposedly hold by Ivan or if it is a hypothesis that Ivan fancies experimenting with.

${ }^{31}$ It should be stressed that Pisarev, after having been released from prison in the second half of the 1860 s, radically changed his view on fanaticism (see Frede 2011, 182).
} 
in the Baltic Sea at the age of 27 (see Coquart 1946, 186-189, 378-381; Pozefsky 2003, 7).

Although Turgenev had given Bazarov several unsympathetic traits, one cannot disregard the fact that in his construction of the character he also emboldened the new generation. Pisarev responded by writing an enthusiastic review that at the time became almost as famous as the book, endorsing the young generation's embrace of nihilism, as well as its coronation of Bazarov as its role model.

But there also arose argument, concerning "Bazarovism" and its nihilistic content, as to its ideological source and who were entitled to embrace it. The significance of Pisarev's position in this struggle can be understood in relation to the consequences it held for the stance that was taken by the young generation's "fathers". Herzen, being one of the latter, argued in 1868, six years after the publication of Turgenev's novel and Pisarev's review (and hence in a different political climate), that the šestidesjatniki's nihilism had essentially been introduced by the sorokovniki. According to Herzen, nihilism should first and foremost be credited as a vehicle of positive change, only to be found in Russia. The movement of nihilism is actually legitimized by Herzen with formulations that echo the proto-Slavophile Pëtr Čaadaev's (1829/1978, 16; 1837/1978, 90-91) view of Russian culture as merely a blank page, having unlimited potentiality, quite in contrast to the history-laden Western Europe, that can redeem and liberate mankind (cf. Herzen 1868/1968, 1763).

Consequently, and not surprisingly, Herzen employs Turgenev's generational dichotomy to state that the "children" are disproportionately disrespectful towards their "fathers". Herzen regrets the disrespectful attitude since the children and the fathers, according to Herzen, are united on many issues and the former are beholden to the latter. The fathers should not behave like the Titan Saturn (Chronos) who devours his children, while the children must not follow the example of those indigenous peoples who supposedly killed off their old ones (ibid., 1753-56). Despite Herzen's regret, it is his hope that the generations one day will be able to meet with sympathy for each other (ibid., 1758).

Turning back to Pisarev's writing, in the beginning of the decade, it appears the ideological generational conflict concerning "Bazarovism" was inescapable. According to Pisarev $(1862 / 1955,11,126)$, Bazarovism, and the "realism" it represents, draws upon those with sufficient spiritual strength, a characteristic by him exclusively attributed to the young. Moreover, they possess the courage and capacity to face the times as they really are, despite whatever haunting social "malady" (Pisarev 1862/1955, 11). This is exactly what "Bazarovism" is: a malady that must be lived through rather than resisted in order for the patient, that is, society, to become healthy again. ${ }^{32}$ The antagonism between sorokovniki and šestidesjatniki actually seems to be irreversible and natural, since "[e]very generation repudiates [razrušaet] the world view of the antecedent generation [...]" (Pisarev 1861/1955, 134).

\footnotetext{
32 Interestingly, one can, in this, see a correspondence between the notion of nihilism as a social malady and Pisarev's own experience of mental illness.
} 


\section{The negation of the past}

Observe that Pisarev does not always approve of the appellation "nihilist". Sometimes he uses it to epitomize the invectives that the young generation must endure (Pisarev 1865/1956b, 7; cf. Herzen 1868/1968, 1764). Overall, however, Pisarev evidently has a positive view of negation (otricanie), a perspective he certainly shares with other radical šestidesjatniki. Destruction, as a form of negation, can lead to something good—given that what is negated is false, immoral or decadent-in accordance, one might figuratively add, with the mathematical rule that two negatives equal a positive.

One of Pisarev's quotes in particular is cited in most retrospective accounts on nihilism:

In short, here is the ultimatum of our camp: what can be smashed [razbit'] must be smashed; whatever will stand the blow will do, what flies into smithereens is rubbish; in any case, strike out [bej] right and left, no harm will or can come of it. (Pisarev 1861/1955, 135)

Pisarev, here, in contrast to what is implied in several accounts (e.g. Fandozzi 1974, 4; Brower 1975, 15; Gillespie 1995, 143; Kline 1999), does not request that the reader physically smash social institutions. Rather, he argues that free speech benefits everyone-except, perhaps, those who lie and have something to hide. The quotation may be motivated by Pisarev's $(1865 / 1956 a, 434)$ markedly negative attitude towards the norms and conventions of official culture. Indeed, in another text from the same year, he pays tribute to WITBD for mocking the arts, disrespecting the public, violating its morality and showing the falseness of its chastity (Pisarev $1865 / 1956 \mathrm{~b}, 8)$. For good reasons, not least with reference to the intransigent style of his literary criticism, in which he repudiates the commonly recognized classics of art, Pisarev has consequently gone down in history as a nihilist in words (Stacey 1974, 63), rather than as a revolutionary in practice (cf. Pozefsky 2003, 4).

Authorities found, in the content of another famous quote, the pretext for which they had been searching in order to arrest Pisarev (he supposedly had tried to publish the pamphlet illegally). Ironically, these are the only manifestly "revolutionary" sentences Pisarev ever wrote (Pozefsky 2003, 6), and thus do not represent his collected work.

The Romanov dynasty and the Petersburg bureaucracy must perish [pogibnut']. They will not be saved by ministers like Valuev or litterateurs like ŠedoFerroti [Fëdor Firks].

That which is dead and rotten will crumple down into the grave of its own; our task is merely to give it the final thrust and bury their stinking corpses in the mud. (Pisarev 1862/1906/1955, 126)

Herzen, whom Pisarev here tries to defend, had well before this incident commented on the disappointing reactionary development after the 1848 revolution in France:

$[\ldots]$ no matter what happens $[\ldots]$ the world, which stands in the way of the new man, preventing him from living and establishing the future, will per- 
ish. And this is splendid. So therefor, long live chaos and destruction! Vive la mort! And let the future come! (Herzen 1855/1955, 48)

This virtually revolutionary statement could indeed be interpreted to mean that the delivery of the future requires the destruction of the past; and as a consequence, the remnants of the past which are contained in the present. Although for Pisarev (cf. $1865 / 1956 b, 9)$ the negation of the past in many respects is figurative and essentially non-violent, this nihilistic idea became subject to a critical literary experiment in Dostoyevsky's (1866/1973, 199-200) Crime and punishment. Here, Raskolnikov, the embodiment of an "extraordinary man" and, as such, "a man of the future", confers to himself the right to commit crimes, under the premise that extraordinary men are "destroyers" (razrušiteli) who affirm "the destruction of the present" for the benefit of humanity. ${ }^{33}$

In a sense, nihilism could be said to ultimately intensify a general impulse of modernity, drawing upon a perspective that was institutionalized during the Enlightenment and the French Revolution, through which crises and social failure stem from problems of the past and solutions belong to the future, which is the reason why the past must be overcome (cf. Koselleck 2002, 167-68). ${ }^{34}$ Ironically, regarding Dostoyevsky's critique, it could, however, be argued that this "nihilistic" thrust, as seen in the philosophy of Friedrich Nietzsche (1889/1988, 310-311), is also detectable in the monotheistic religions - the alleged bulwark against "modern" nihilism. ${ }^{35}$

\section{The ambivalences of nihilism}

In his "Bazarov" review, Pisarev (1862/1955) most comprehensively analyzes Bazarovism. Bazarovism is not only the defining characteristic of the Zeitgeist; it possesses it as a "malady", a disease that must be lived through. Bazarov recognizes the importance of negating or rejecting prevailing authorities, institutions and ideals and this, according to Pisarev (1862/1955, 18, 20-21), therefor excuses the use of the term nihilism. But Pisarev (ibid., 24-26) is not entirely comfortable with highlighting negation as such: It risks becoming arbitrary and despotic. When Bazarov

\footnotetext{
33 "Extraordinary man" (neobyknovennyj) alludes to Chernyshevsky's (1863/1974, 283) "special man" (osobennyj), the latter who is presumed to exist in "few" numbers and belong to a "rare" kind. The emblem of such a man, Rakhmetov, is referred to by Pisarev $(1865 / 1956 b, 44)$ exactly as an "extraordinary man".

34 There is, however, a difference between intending to overcome and destroy the past, even if long-term consequences might be identical. As Verhoeven $(2009,7)$ points out, modernity always provides material conditions for the emergence of new sovereign subjects, who, violently or not, can act for the sake of "universal redemption".

35 The nihilistic contents of the monotheistic religions are present to the degree that the latter tend to define the natural world in terms of "secondary-ness", or, consequently, as sin and decay, and also, form identity or define ethics antagonistically or ascetically. In the case of Christianity, "negation" can precisely become the mode of operation in championing new life in Christ and things becoming, rejecting status quo through conversion, baptism, confession, charity and continuing mission. In the Russian tradition, the link between religion and nihilism has e.g. been noted by Berdyaev (1937/1990, Ch. 2). In contrast to Nietzsche, however, Berdyaev's interest does not concern the nihilistic potential of religion as much as the religious contents of (Russian) nihilism, and eventually communism.
} 
dismisses the writing of poetry, playing music and respecting nature as ridiculous and absurd, such rejections, we are told, represent an estrangement from "empiricism". One cannot, concludes Pisarev, arbitrarily condemn only the talents and abilities that oneself has not developed, or the need we all seem to have of recreation in nature.

In his review, Pisarev, the self-claimed "realist", not surprisingly concludes that realism is more important to Bazarovism than negation. Even in realism, however, there is a negative implication. This becomes particularly evident in Bazarov's cynicism, even though for Pisarev cynicism is ultimately a constructive attitude. This cynicism is a hallmark of Bazarovism, which Pisarev (1862/1955, 31) suggests is more elaborate, well thought-out and consistent than Turgenev apparently would admit. Bazarov's "tenacious scepticism", and with it the inclination to use negation and rejection, does not contradict, but rather it reinforces the notion that he is ultimately "a man of life, a man of action", with admirable "power, independence, energy" (ibid., 45). As a nihilist, Bazarov is a person with complete trust in his own abilities (ibid., 46).

As I understand Pisarev, the cynicism of Bazarovism has two aspects, one internal and one external, which together indicate the dialectical character of the concept of nihilism. The former aspect concerns cynicism of thought and feeling; the latter, cynicism of manners and expressions. Internal cynicism is characterized by an ironic approach to emotions, reverie and poetical excesses. External cynicism refers to the rough, harsh and plebeian ways in which the former cynicism or irony is communicated. It is hardly a coincidence that Bazarov is compared to the cynic Diogenes of late Greek antiquity (ibid., 12, 16). Pisarev (ibid., 12) argues that this (internal) cynicism is a function of a particular worldview accessible to Bazarov by virtue of his reason. Meanwhile, external cynicism is more conditioned by the objective social circumstances that surround the cynic. Pisarev is apparently focused on external cynicism, for it is the cynical subject that stands at the centre, with whom Pisarev himself identifies, and in turn projecting this onto the young generation. Bazarov is, as he says, "an incarnation of the theory of nihilism" (Pisarev 1862/1955, 47).

As presaged in $F \& C$, the nihilist will not be able to breathe in empty nothingness. Indeed, Bazarov, despite his pretension to independence, is, at the end of the story, destroyed by unrequited love to Madame Odincova. Pisarev offers a solution to this problem in his review of WITBD, that is found in "The Thinking Proletariat" (1865/1956b). He admits that Bazarov has unsympathetic traits, such as insensitivity and egocentricity. Pisarev suggests, however, that because Turgenev lacked enough material for Bazarov's character and story development, he is, in effect, leaving Bazarov in a social vacuum. Since Turgenev belongs to an older generation, and consequently holds its political and philosophical outlook, he is unable to understand his own fictional character (Pisarev 1862/1955, 31)-Turgenev himself "can never become a Bazarov" (ibid., 26). Pisarev believes that Bazarov would have interacted differently if he were situated with fellow "Bazarovs". Now, in a vacuum, or surrounded by people with essentially different mental constitutions who cannot meet Bazarov's intellectual abilities, he stands out as rootless and rigid, uncaring and disrespectful (Pisarev 1865/1956b, 11-12)_- "Only in the relations with one another do new people develop all the strengths of their character and all their 
abilities of their reason [...]" (Pisarev 1865/1956b, 39) ${ }^{36}$ Taken together with the prospect that the number of these new people joining the movement will constantly multiply (ibid., 7), due to the popularity of the Bazarov character, Pisarev is left to conclude that nihilism in due course will become more humane.

Pisarev does not agree that Bazarov is a caricature; rather, the fictional character has been left incomplete by Turgenev. For example, the reader is not informed about Bazarov's student background, and therefor does not know what he may have experienced during those days (Pisarev 1864/1956, 15, 1862/1955, 37). A fuller description would according to Pisarev not necessarily give a more coherent picture of Bazarov. Pisarev $(1862 / 1955,9)$ acknowledges inconsistency in how Bazarov acts in relation to what he says in words. However, Pisarev implies that this "double standard" is what possibly saves Bazarov from moral self-annihilation. Such "positive" duality of nihilism is not, I contend, acknowledged by the antinihilistic writers Dostoyevsky, Pisemsky or Leskov. In any case, the contradiction, for Pisarev $(1864 / 1956,46)$, validates the assumption that Bazarov does not have a "rigorist" nature. This is shown, for example, when Bazarov refers to "love" intellectually in one way and personally acts when being in love in a completely different way. For Pisarev, the presumed element of rigorism is exactly what has defined nihilists and realists in an unfavourable way.

Like so many other Russian radicals, Pisarev (cf. 1865/1956b, 7, 46-47) is an elitist in the sense that he believes in the significance of a political avant-garde. According to him, the revolutionary elite grows in number every hour and so eventually will number hundreds of "Bazarovs". The implication that nihilism will be humanized can be seen as an early moderation of the tension that would emerge between the two inherent poles of nihilism: (i) ruthless insensitivity, as embodied by Bazarov and Rakhmetov (cf. Turgenev 1862/1981, 27-28; Chernyshevsky 1863/1974, 279-80); and, (ii) unconditional sensuousness, that is, "egoistically" acting out of emotions for the benefit of humanity, as the main protagonists try to do in WITBD (cf. Chernyshevsky 1863/1974, 73, 185, 211-212, 245, 262, 336, 359-360). In this sense, despite its radical stance, Russian nihilism is built up of a reconciliation of opposites.

\section{Conclusions}

Although the nihilist movement struggled for autonomy and aimed at paving the way for a new society, the movement was ironically stuck in the past, continuously negating its sources of inspiration. Considering that the sorokovniki were aware of their contribution to the development of the radical ideas of the šestidesjatniki, one

\footnotetext{
36 Pisarev offers a clue to how Bazarov would have interacted with peers, by considering the radical community presented in WITBD, where the "nihilist" protagonists Vera Pavlovna, Lopukhov and Kirsanov emerge as more sympathetic and where emphasis is not on negation, but on the vision of an egalitarian society, with free love rather than cold rationality at the centre. Pisarev argues that if these characters had been placed in the unpleasant context provided in $F \& C$ they would all have become "Bazarovs".
} 
might wonder whether the hostile and irreconcilable stance occasionally taken by the younger generation was in part a projection of their own sense of failed emancipation from and indebtedness to their "fathers". Furthermore, the šestidesjatniki may have been unconsciously influenced by the idealism of the sorokovniki. The dual relationship of dependence and confrontation, resulting in a continuous engagement with each other's ideas, might explain why so many distinctly idealistic notions are reflected among the materialistic nihilists, such as the emphasis on individual autonomy, power, energy, life, action and independence.

Russian nihilism is very far from a uniform phenomenon. There are distinctly diverse or even conflicting elements expressed, not only by different advocates of nihilism but also by one and the same writer over time, the latter as for example can be seen in the social criticism of Pisarev. The threat of censorship and repression from the Tsarist regime can explain some of this diversity, stimulating the ability to adapt to different situations. Another factor, however, is probably the suppressed dependency of the šestidesjatniki upon the sorokovniki, which is reflected in the versatility of the nihilist persona. The labels-nihilists, realists, materialists, people of science/action, egoists, new/special people, cynics, altruists, liberators, revolutionaries, terrorists, destroyers-appear as different facets, but these are knotted together within a particular dialectics of social discourse, accommodating the processes of ideological radicalization as well as of moderation. Depending on circumstance, one or another label could be appropriated to meet the demands of the situation, whether by nihilists or antinihilists (cf. Pozefsky 2003, 8), each for their unique reason and, accordingly, with different aims and effects.

In previous popular as well as some general accounts on Russian nihilism, the desire for universal negation has been emphasized, Gillespie $(1995,173)$, for example, portraying the nihilists as quasi-religious worshipers of the "dark god of negation". In this paper, I have argued that by restoring Russian nihilism based on its primary sources one will get a partly different picture of the movement. Within Russian nihilism a tension exists between the need for particular negations, on the one hand, and a desire for universal negation, on the other, i.e., between tactical, limited-focus and indiscriminate negation-the latter instantiating the "eternal Spirit" of continuing destruction (and universal revolution). "Negation", following Pisarev, means breaking with certain norms, values and traditions, and not smashing social reality itself.

The philosophical essence of Russian nihilism lies in the negation of deformation for the sake of affirmation - of that which has not yet become. Indeed, the idea that one could clear the impediments of the emergence of the future by destroying the remnants of the past in the present could also be seen as a radical interpretation of the ethos of modernity, if not of other aspects of human culture in a wider sense. That is, obstacles and problems are increasingly associated with the past, which is why it is imperative for contemporary generations to break with history. Russian nihilists did not primarily see their negations as ends in themselves-many examples of which should not be interpreted literally-rather, they were basically driven by a positive vision for a future society, which could be approached either step-by-step (Vera Pavlovna) or in one sweep (Rakhmetov); and, from the viewpoint of Pisarev, such use of negation would be guided by the aim that the harder sides of 
the movement eventually should be neutralized. Every non-fictional nihilist should not be a Rakhmetov, but more so a Lopukhov or a Vera Pavlovna. Russian nihilism-significantly a generation-bound phenomenon-therefor is manifested more as a freedom-maximizing youth culture, and less as the extreme manifestations of eccentric evil-doers.

The positive ideals of a universal utopia do not, however, justify all of the negative implications which it might harbour. Even though becoming "fanaticized" is in the younger Pisarev's eyes a virtue, the commitment or legitimation of terrorist acts among some of the more fervent Russian nihilists, may principally have had the same negative effect on human and cultural pluralism as have had, in other contexts during modern history, different kinds of fanaticism-be they "progressive" or not. The pursuit of negation is recognizable in what Christian missionaries induced during the heyday of Western colonialism, as they sought, at any cost, to save souls to the Church by correcting the Native from sinful manners. A parallel is also the Stalinist apparatchik that tenaciously set out to implement doctrines of Soviet communism in traditionally non-Soviet regions, regardless of circumstances. More recently, the Jihadist warrior comes to mind, "inviting" (dawah) unbelievers to convert themselves to "true" Islam by violently prohibiting that which is haram (forbidden) while enjoining what is supposed to be halal (allowed). All these fanatics, nihilists included, were guided by the most righteous of motives. Russian nihilism may have been an atheist movement but its genealogy has secular as well as religious roots, where the common denominator is not only spelled out in the obvious dialectic between destruction and renewal, death and rebirth, but also in the specious zeal of imposing goodness and purity on to others, sanctified by the notion of a "superior" religion, civilization or ideology.

Acknowledgements The article was written at the Department of Political, Historical, Religious and Cultural Studies as well as the Research Group for Culture Studies (KuFo) at Karlstad University. I would like to thank my colleagues and friends at the university for all creative discussions from which I have benefitted immensely.

OpenAccess This article is distributed under the terms of the Creative Commons Attribution 4.0 International License (http://creativecommons.org/licenses/by/4.0/), which permits unrestricted use, distribution, and reproduction in any medium, provided you give appropriate credit to the original author(s) and the source, provide a link to the Creative Commons license, and indicate if changes were made.

\section{References}

Alekseev, M. (1928). K istorii slova nigilizm. In V. Peretc (Ed.), Sbornik statej v čest' akademika Alekseja Ivanoviča Sobolevskogo (pp. 413-417). Leningrad: AN SSSR.

Andrén, M. (2014). Nihilism and responsibility in the writings of Karl Jaspers. European Review, 22(2), 209-216.

Bäckström, P. (2010). 'L'art, expression de la Société, est précurseur et révélateur': The heterogenity of the notion of 'Avant-Garde'. In K. Bergman et al. (Eds.), Norlit 2009: Codex and code: Aesthetics, language and politics in an age of digital media. Linköping Electronic Conference Proceedings (Vol. 42, pp. 61-79). Linköping: LU Electronic Press. http://citeseerx.ist.psu.edu/viewdoc/download ?rep=rep1\&type=pdf\&doi=10.1.1.211.347. Cited September 26, 2017. 
Bakunin, M. (1842/1972). The reaction in Germany: From the notebooks of a Frenchmen. In S. Dolgoff (Ed.), Bakunin on anarchy: Selected works (pp. 55-57). New York: Knopf.

Berdyaev, N. (1937/1990). Istoki i smysl russkogo kommunizma. Moscow: Nauka.

Berlin, I. (1994). Fathers and children: Turgenev and the liberal predicament. In H. Hardy \& A. Kelly (Eds.), Russian thinkers (pp. 261-305). London: Penguin Books.

Billington, J. H. (1970). The icon and the axe: An interpretive history of Russian culture. New York: Vintage books.

Brower, D. R. (1975). Training the nihilists: Education and radicalism in Tsarist Russia. Ithaca, NY: Cornell U.P.

Brumfield, W. C. (1977). Bazarov and Rjazanov: The romantic archetype in Russian nihilism. Slavic and East European Journal, 21(4), 495-505.

Čaadaev, P. (1829/1978). Pis'mo pervoe [published in 1836]. In P. Čaadaev (Ed.), Filosofičeskie pis'ma $i$ Apologija sumaš̌eď̌ego (pp. 6-26). Ann Arbor: Ardis.

Čaadaev, P. (1837/1978). Apologija sumasšedšego. In FPIA (pp. 79-94).

Carr, E. H. (1937/1975). Michael Bakunin. London: Macmillan.

Carter, K. (2015). The political and social thought of F.M. Dostoevsky. New York: Routledge.

Chernyshevsky, N. (1860/1974). Antropologičeskij princip v filosofii. In N. Chernyshevsky (Ed.), Sobranie sočinenij (Vol. 4, pp. 200-295). Moscow: Pravda.

Chernyshevsky, N. (1863/1974). Čto delat'?: Iz rasskazov o novykh ljudjakh. In N. Chernyshevsky (Ed.), Sobranie (Vol. 1). Moscow: Pravda.

Cochrane, S. (1977). The collaboration of Nechaev, Ogarev, and Bakunin in 1869: Nechaev's early years. Giessen: Wilhelm Schmitz Verlag.

Coquart, A. (1946). Dmitri Pisarev (1840-1868) et l'ideologie du nihilisme russe. Paris: Inst. d'Études slaves de 1'Univ. de Paris.

Dostoyevsky, F. (1866/1973). Prestuplenie i nakazanie. In F. Dostoyevsky (Ed.), Polnoe sobranie sočinenij (Vol. 6). Leningrad: Izdatel'stvo Nauka.

Dostoyevsky, F. (1872/1974). Besy. In F. Dostoyevsky (Ed.), PSS (Vol. 10). Leningrad: Izdatel'stvo Nauka.

Dostoyevsky, F. (1880/1976a). Bratia Karamazovy: Kniga I-X. In F. Dostoyevsky (Ed.), PSS (Vol. 14). Leningrad: Izdatel'stvo Nauka.

Dostoyevsky, F. (1880/1976b). Bratia Karamazovy: Kniga XI-XII. In F. Dostoyevsky (Ed.), PSS (Vol. 15). Leningrad: Izdatel'stvo Nauka.

Dubnov, A. M. (2015). 'Those new men of the sixties': Nihilism in the liberal imagination. Rethinking History, 19(1), 18-40.

Elizavetina, G. (1992-2003). Pisarev-Kritik, 3 vols. Moscow: Nasledie/IMLI RAN.

Ely, C. (2016). Underground Petersburg: Radical populism, urban space, and the tactics of subversion in reform-era Russia. DeKalb: Northern Illinois UP.

Fandozzi, P. R. (1974). The Heideggerian perspective on nihilism: A critique of modern technology through its manifestations in literature, philosophy and social thought. Dissertation, University of Hawaii.

Frank, J. (1967). N. G. Chernyshevsky: A Russian utopia. Southern Review, New Series, 3(Winter), 68-84.

Frede, V. (2011). Doubt, atheism, and the nineteenth-century Russian intelligentsia. Madison, WI: Wisconsin UP.

Freeborn, R. (1998). Introduction. Fathers and sons (pp. vii-xxii). Oxford: Oxford UP.

Gillespie, M. A. (1995). Nihilism before Nietzsche. Chicago: Chicago U.P.

Hegel, G. W. H. (1807/1980). Phänomenologie des Geistes. In W. Bonsiepen \& R. Heede (Eds.), Gesammelte Werke (Vol. 9). Hamburg: Felix Meiner Verlag.

Herzen, A. (1855/1955). S togo berega. In A. Herzen (Ed.), Sobranie sočinenij (Vol. 6, pp. 7-142). Moscow: AN SSSR.

Herzen, A. (1860/1968). The superfluous and the jaundiced. In A. Herzen (Ed.), My past and thoughts: The memoirs of Alexander Herzen (Vol. 4, pp. 1574-84) (Trans., C. Garnett). London: Chatto \& Windus.

Herzen, A. (1868/1968). Bazarov once more. In A. Herzen (Ed.), My past and thoughts (pp. 1750-1765). London: Chatto \& Windus.

Katz, M. (1966). Mikhail N. Katkov: A personal biography 1818-1887. Mouton: The Hague.

Kline, G. L. (1999). Russian nihilism. In R. Audi (Ed.), The Cambridge dictionary of philosophy (2nd ed., p. 805). Cambridge: Cambridge University Press. 
Koselleck, R. (2002). The practice of conceptual history: Timing history, spacing concepts (Trans. T. S. Presner et al.). Stanford: Stanford U.P.

Kuznecov, F. (Ed.). (1984). Šestidesjatniki. Moscow: Sovetskaja Rossija.

Kuznecov, F. (1983). Nigilisty? D.I. Pisarev i žurnal "Russkoe slovo”. Moscow: Chudožestvennaja literatura.

Leskov, N. (1864/1989). Nekuda. In N. Leskov (Ed.), Sobranie sočinenij v 12 tomakh (Vol. 4). Moscow: Pravda.

Lincoln, W. B. (1990). The great reforms: Autocracy, bureaucracy, and the politics of change in imperial Russia. DeKalb: Northern Illinois U.P.

Lovell, S. (1998). Nihilism, Russian. In E. Craig (Ed.), Routledge encyclopedia of philosophy (Vol. 7, pp. 5-8). London: Routledge.

Malia, M. (1961). Alexander Herzen and the birth of Russian socialism, 1812-1855. Cambridge, MA: Harvard UP.

Moser, C. A. (1964). Antinihilism in the Russian novel of the 1860's. The Hague: Mouton \& Co.

Müller-Lauter, W., \& Goerdt, W. (1984). Nihilismus. In J. Ritter \& K. Gründer (Eds.), Historisches Wörterbuch der Philosophie (Vol. 6, pp. 846-854). WBG: Darmstadt.

Nahirny, V. C. (1962). Some observations on ideological groups. American Journal of Sociology, 67(4), 397-405.

Nechayev, S. (1869/2010). Katekhizis revoljucionera. In Istoričeskie istočniki na russkom jazyke v Internete. Ėlektronnaja biblioteka Istoričeskogo fakul'teta MGU. http://www.hist.msu.ru/ER/Etext/necha ev.htm. Cited July 21, 2017.

Nietzsche, F. (1889/1988). Ecce Homo: Wie man wird was man ist. In G. Colli \& M. Montinari (Eds.), Sämtliche Werke: Kritische Studienausgabe in 15 Bänden (Vol. 6, pp. 255-374). Munich: DTV/de Gruyter.

Novikov, A. (1972). Nigilizm i nigilisty: Opyt kritičeskoi kharakteristiki. Leningrad: Lenizdat.

Olson, R. G. (1967). Nihilism. In P. Edwards (Ed.), The Encyclopedia of Philosophy (Vol. 5, pp. 514517)., 3 vols New York: The Macmillan Company and The Free Press.

Paperno, I. (1988). Chernyshevsky and the age of realism: A study in the semiotics of behavior. Stanford, CA: Stanford UP.

Petrov, K. (2006). Tillbaka till framtiden: Modernitet, postmodernitet och generations-identitet $i$ Gorbačevs glasnostóch perestrojka. Södertörn doctoral dissertations 11. Huddinge: Södertörn University.

Pisarev, D. (1861/1955). Skholastika XIX veka. In D. Pisarev (Ed.), Sočinenija v četerëkh tomakh (Vol. 1, pp. 97-159). Moscow: Gos. izd. Khudožestvennoj literatury.

Pisarev, D. (1862/1955). Bazarov. In Soč. (Vol. 2, pp. 7-50).

Pisarev, D. (1862/1906/1955). O brošjure Šedo-Ferroti. In Soč. (Vol. 2, pp. 120-26).

Pisarev, D. (1864/1956). Realisty. In Soč. (Vol. 3, pp. 7-138).

Pisarev, D. (1865/1956a). Razrušenie èstetike. In Soč. (Vol. 3, pp. 418-35).

Pisarev, D. (1865/1956b). Mysljaščiij proletariat. In Soč. (Vol. 4, pp. 7-49).

Pozefsky, P. C. (2003). The nihilist imagination: Dmitrii Pisarev and the cultural origins of Russian radicalism, 1860-1868. New York: Peter Lang.

Randolph, J. (2011). The house in the garden: The Bakunin family and the romance of Russian idealism. Ithaca, NY: Cornell UP.

Scanlan, J. P. (1967). Nikolaj Černysevskij and Soviet philosophy. Studies in Soviet Thought, 7(1), 1-27.

Schapiro, L. (1978). Turgenev: His life and times. New York: Random House.

Schmidt, W.-H. (1974). Nihilismus und Nihilisten: Untersuchungen zur Typisierung im russischen Roman der zweiten Hälfte des neunzehnten Jahrhunderts. Munich: Fink.

Siljak, A. (2008). Angel of vengeance: The girl who shot the governor of St. Petersburg and sparked the age of assassination. New York: St. Martin's Griffin.

Skinner, Q. (1988). A reply to my critics. In J. Tully (Ed.), Meaning and context: Quentin Skinner and his critics (pp. 231-288). Princeton, NJ: Princeton U.P.

Stacey, R. H. (1974). Russian literary criticism: A short history. Syracuse, NY: Syracuse U.P.

Stites, R. (1978). The women's liberation movement in Russia: Feminism, nihilism, and Bolshevism 1860-1930. Princeton U.P: Princeton.

Stokes, K. M. (1995). Paradigm lost: A cultural and systems theoretical critique of political economy. Armonk, NY: M.E. Sharpe.

Thorstensson, V. (2013). The dialog with nihilism in Russian polemical novels of the 1860s-1870s. Dissertation, University of Wisconsin-Madison. 
Turgenev, I. (1862/1981). Otcy i deti. In Sočinenija (Vol. 7). Moscow: Izdatel'stvo Nauka.

Verhoeven, C. (2009). The odd man Karakozov: Imperial Russia, modernity, and the birth of terrorism. Ithaca, NY: Cornell UP.

Višnjakova, O. (2011). Russian nihilism: The cultural legacy of the conflict between fathers and sons. Comparative and Continental Philosophy, 3(1), 99-111.

Vucinich, A. (1988). Darwin in Russian thought. Berkeley, CA: California U.P.

Walicki, A. (1979). A history of Russian thought: From the Enlightenment to Marxism (Trans. H. Andrews-Rusiecka). Stanford: Stanford U.P.

Zrjačkin, A. (2009). Pravavoj nigilizm: Pričiny i puti ikh oreodolenija. Saratov: SGAP.

Publisher's Note Springer Nature remains neutral with regard to jurisdictional claims in published maps and institutional affiliations. 